\title{
Tackling inflation in Nigeria: Monetary or fiscal policy? An empirical assessment of the effectiveness of the simultaneous implementation of the policies
}

\author{
Ibrahim Abdulhamid Danlami1, Mohamad Helmi Bin Hidthiir2, Sallahuddin Hassan3 \\ ${ }^{1}$ Department of Social Science and Administration, School of Continuing Education, Bayero University, Kano, \\ Nigeria \\ ${ }^{2,3}$ School of Economics Finance and Banking, Universiti Utara Malaysia \\ Corresponding author: adanlami.sce@buk.edu.ng
}

Received: 25 June 2019 Revised: 11 July 2019 Accepted: 26 June 2019 Published: 30 Jun 2020

\begin{abstract}
The study is aimed at empirically assessing between monetary policy and fiscal policy, the most effective in combating and tackling inflation in Nigeria, especially when implemented simultaneously - the effect of the concurrent implementation of the two policies on inflation. The variables of the policies are based on market information, money market equilibrium (LM Curve) for monetary policy, and product market equilibrium (IS Curve) for fiscal policy. The research makes use of the Autoregressive Distributed Lag Model (ARDL). Data for Nigerian was used from 1970 - 2016. The findings show that monetary and fiscal policies can be implemented concurrently as monetary policy is the best for a short-run solution during the fiscal policy for a long-run solution. The findings of the study are based on Nigerian data utilized for the period $1970-2016$ and the method of data analysis adopted - ARDL, as well as variables selection based on the general equilibrium of money and product market. The findings of the study clearly show that monetary and fiscal policies can be used simultaneously to tackle inflation in Nigeria successfully, being effective in combating inflation in different periods (short-run or long-run). The study attempted to harmonize the incompatible theories and their policies to see whether the policies can be utilized concurrently since the policies are aimed at effecting price stability. The research's findings confirm the feasibility of implementing the two policies concurrently and their effects to be felt or realized in different periods - short-runs and long-runs.
\end{abstract}

Keywords: ARDL, Fiscal policy, Monetary policy, Nigeria, Stabilization policies. 


\section{INTRODUCTION}

The global competitiveness for financial transactions and other related businesses made it necessary for every country to quest and seek for ways of making their environments conducive for businesses and for organizations to be carrying out their transactions. The quest for favorable business environments by investors necessitated countries to hold firmly onto stabilization policies (monetary and fiscal policies) for the purpose of having sustainable price stability, which is also one of the prerequisites for setting up a conducive business environment (Danlami, 2020; Danlami, Hassan \& Hidthiir, 2020).

The private means of production contribute greatly to output growth. Also, the major aim of stabilization policies (monetary and fiscal policy) is to maintain low level of inflation rate, because price stability results and works toward declining costs and wither away economic inefficiencies, help firms to identify desirable and qualitative investment opportunities and put their funds in various enterprises that will guarantee high returns (Wang, Chen, Chen \& Huang, 2016). They further argued that there is a strong connection between inflation and the decision taken by investors or managers. Therefore, the management or investors' decisions should be taken into consideration while making macroeconomic policies; failure to take this into cogitation would result in missing out a crucial connection or link between investment decisions taken by investors on inflation.

Developing countries are considered to have reasonable prices stability if they have maintained and retained single-digit inflation rate, while an inability to retain single-digit inflation rate by any country, such country is considered to have high rate of price fluctuation majorly inflation (Babalola, Danladi, Akomolafe \& Ajiboye, 2015; Phiri, 2012; Danlami, Hidthiir \& Hassan, 2017; Risso \& Sanchez-Carrera, 2009; Anwar \& Islam, 2011). Having observed the Nigerian inflation rate for a period 1970 - 2016 (47 years), Figure 1 shows that the inflation rate in the country has been double-digit for more than 60 percent of the observed periods with an average of 18.59 percent inflation rate. Meanwhile, the country is also among the developing economies that are struggling to make the business environment better to attract investors (local and foreign investors) to boost their economies. 


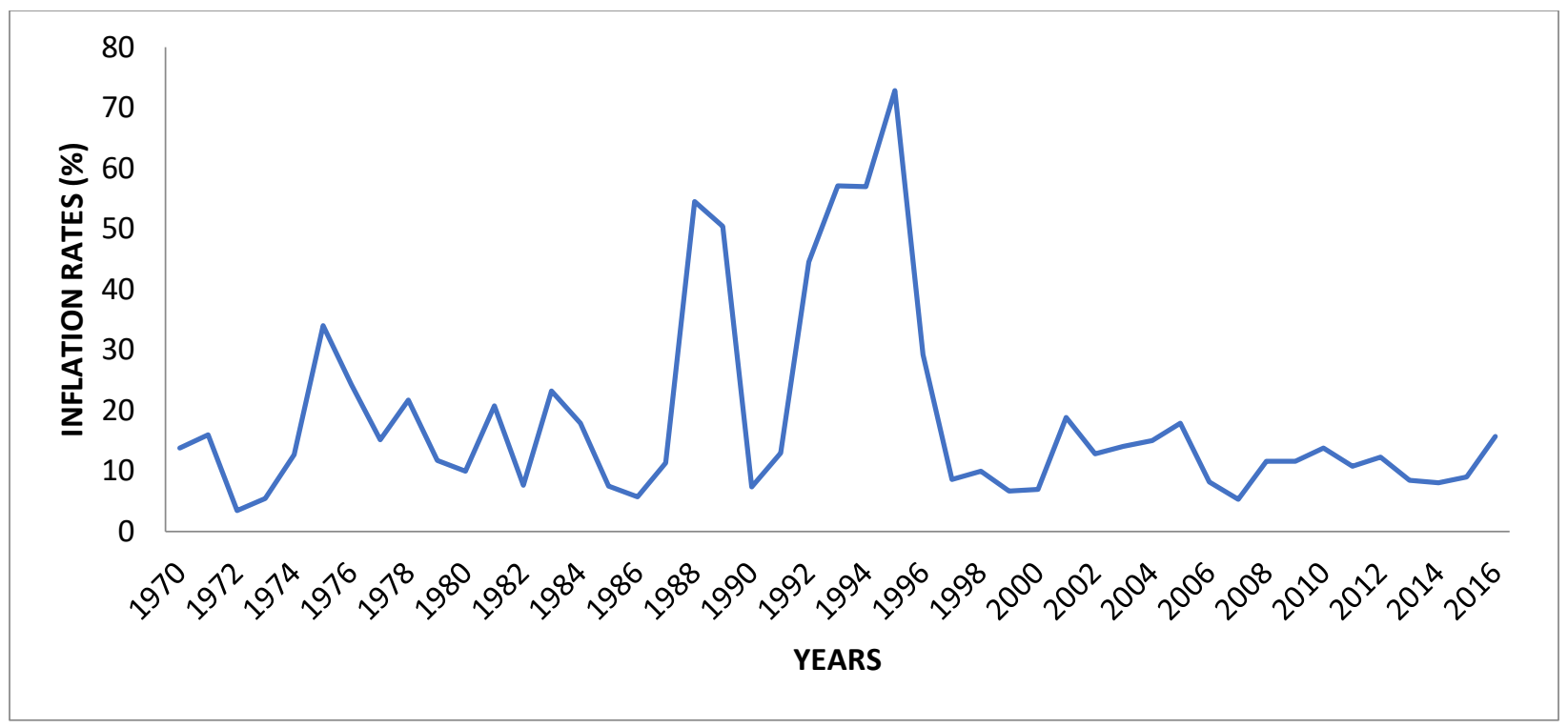

Figure 1: Nigerian Annual Inflation Rates, 1970 - 2016

Source: World Development Indicators, 2018

The frequent occurrences of the worldwide financial crises (2008 worldwide and 2015/2016 that affects oil-producing countries) indicate the need for countries to revisit their stabilization policies' maps and the process of implementations. In addition to this, increases in public borrowing, insufficient ways of mobilizing government revenues and the perpetual increase of fiscal deficits as well as unruly and turbulent inflation rates (taking Nigeria as an example and other oilproducing countries); once again necessitated the need, by so many countries and economies around the globe, to revisit the strategies of their respective stabilization policies to bail their respective economies (Kandil, 2015). Such worldwide economic recessions have necessitated analysts and researchers to revisit various already developed models of stabilization policies, which in turn result in documenting the upshot of economic uncertainties and divergences between theoretical literature and empirical studies (Hartmann, Herwartz \& Ulm, 2016).

Having ascertained that the rates of inflation in Nigeria are very high (beyond the recommended single-digit as indicated in Figure 1) despite the implementations of stabilization policies at different times, calls for the need to investigate whether the two stabilization policies can be possibly implemented simultaneously. This research intends to empirically assess between monetary policy and fiscal policy, the most effective in combating and tackling inflation in Nigeria, especially when implemented simultaneously - the effect of the concurrent implementation of the two policies on inflation. The rest of the research entails these sections; 
related literature is reviewed in section two, while the methodology utilized in this study is highlighted in section three. Section four contains presentations of results and discussions of finding and finally, section five concludes the paper.

\section{Literature Review}

In most times, stabilization policies consist of monetary and fiscal policy that theoretically baked by monetarist and neokeynesian, respectively. Monetary policy involves the regulation of the money supply through controlling the capability of commercial banks to give credits, by the central bank, for the purpose of achieving one or some of the macroeconomic objectives such as price stability or inflation control (Jhingan, 2011). It could be expansionary or contractionary to increase the money supply or reduce it. A simple contractionary monetary policy is shown in Figure 2 and how it works as a remedy for price instability, specifically inflation. It forced adjustment in the money market (LM curve) and forced the LM curve to shift inward from LM0 to LMe, the general equilibrium (intersection between LM and IS curve) changed from point 'c' to point 'e.' The total income of the economy reduces from $Y_{1}$ to $Y_{e}$ and interest rate increases from $r_{1}$ to $r_{e}$ as depicted in Figure 2. 


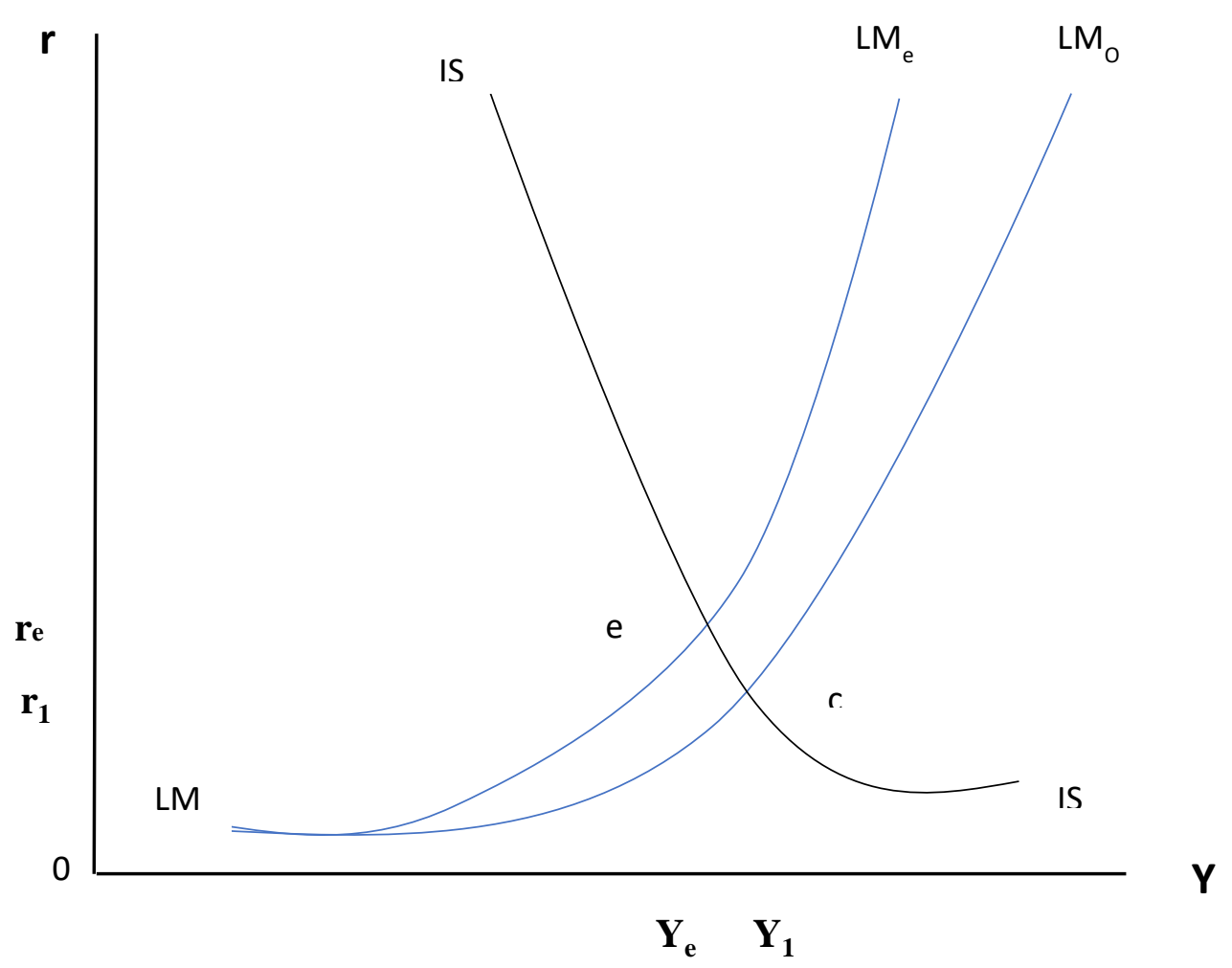

Figure 2: Contractionary monetary policy

Source: Jhingan, 2011

On the other hand, fiscal policy refers to the deliberate action by the government to increase or decrease its receipts or expenditures for the purpose of tinkering the economy as a whole (Jhingan, 2011). Like monetary policy, fiscal policy can be expansionary (a budget deficit) to boost the aggregate demand or contractionary (a budget surplus) to reduce aggregate demand and to control inflation. A simple contractionary monetary policy is shown in Figure 3, and how it works through adjusting the real market equilibrium (IS curve) which forces it to shift inward from IS 1 to ISe and the general equilibrium changed from point 'c' to point 'e.' Total income reduces from $Y_{1}$ to $Y_{e}$ and interest rate reduces from $r_{1}$ to $r_{e}$. 


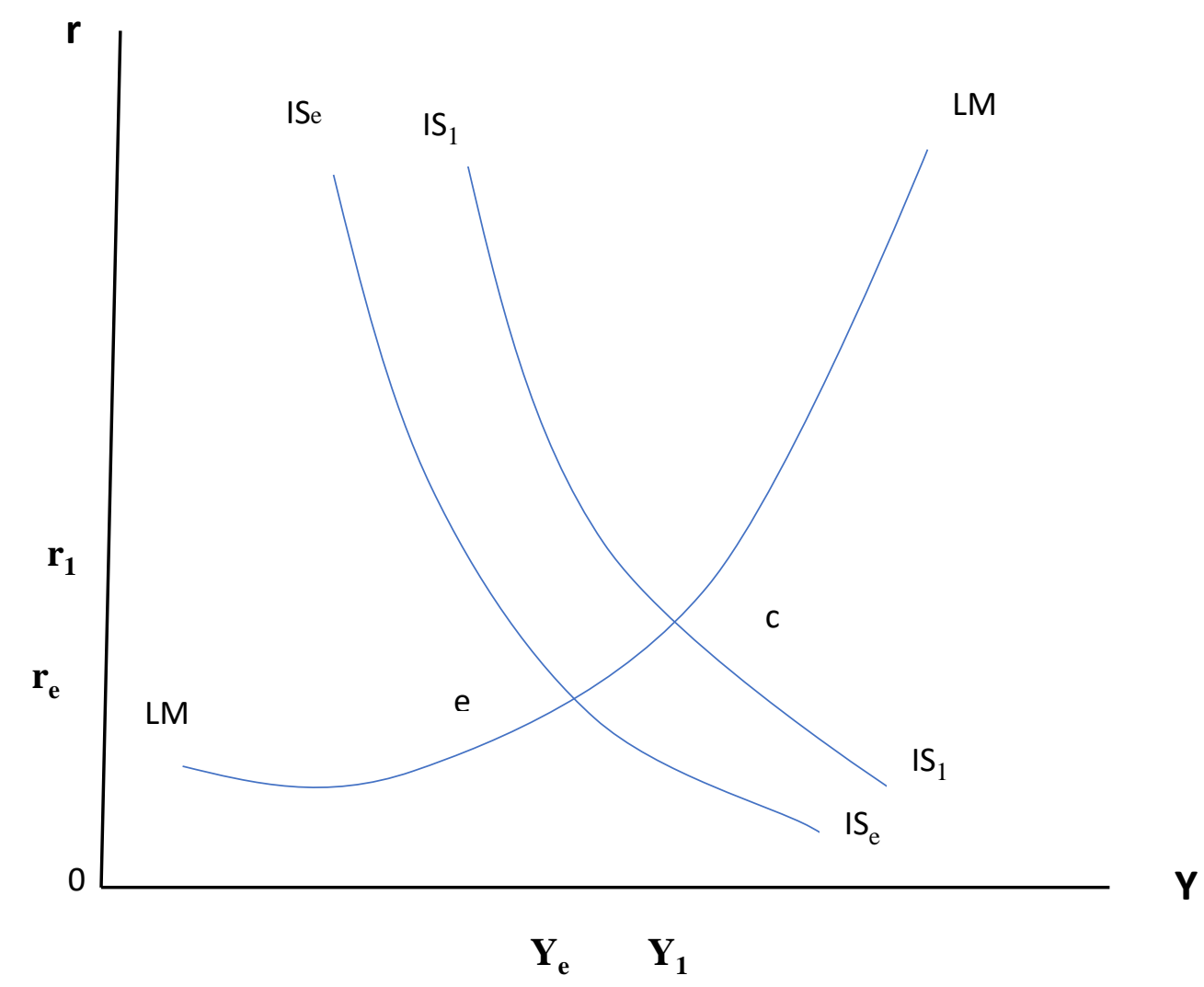

Figure 3: Contractionary fiscal policy

Source: Jhingan, 2011

It is of high significance to note that both contractionary monetary and fiscal policies cause reductions in the total income of the economy, but monetary policy causes an increase in interest rate (inverse effect of interest rate on inflation) while fiscal policy causes a decrease in interest rate (direct effect of interest rate on inflation).

Some empirical studies were done to analyze the effectiveness of the stabilization policies, especially when implemented simultaneously. Alavi, Moshiri and Sattarifar (2016) analyzed the efficacy of the monetary and fiscal policy policies on Iran's economy using the IS-MP-AS model, and the results show that the policies are simultaneously very efficient on stabilizing Iran's economy. Albonico and Rossi (2017) investigated the optimality of monetary and fiscal policies in an economy constrained with limited participation of asset-market. The result shows that fiscal policy is more aggressive when the economy experiences markup shocks, even though 
discretionary policies result in welfare gains to the liquidity constrained consumers and welfare losses to the Ricardians.

Bianchi and Ilut (2017) measured the consequences of the mixed implementation of monetary and fiscal policies before and after Volcker disinflation in the US. The results reveal that the mixture of the policies through the ' $60 \mathrm{~s}-{ }^{\prime} 70 \mathrm{~s}$ caused high inflation. Whereas, the monetary policy changed to Volcker leads to a drop in the inflation rate only when simultaneously implemented with fiscal policy. In their investigation, Cavalcanti et al., (2018) studied the macroeconomic effect of shocks of the monetary policy with the constant fiscal rule on the Brazilian economy. The result reveals that the economy had worse performance, especially when the cuts in public investments cushion the fiscal adjustment.

Cevik, Diboglu and Kutan (2014) used quarterly data from 1995 - 2010 of emerging European economies to examine the effectiveness of the monetary and fiscal policy interaction on the respective economies. The results show evidence of the existence of heterogeneity or diversity among different economies before 2000, while monetary policy is passive after 2000 in all the countries. Da Silva and Vieira (2017) used a panel of 113 combinations of both developing and advanced economies in dual periods 2001-2008, which is described as the pre-crisis period and 2009 - 2012 as post-financial crises period. The study applied a dynamic system GMM, and the results show that in advanced economies, monetary policy responses contrary to the fluctuations of the economic cycles before the advent of the financial crises period only, while fiscal policy behaves in accordance and consistent with the fluctuations of the economic cycle in the mentioned period only. Also, from the result, the interest rate has been considered to be the most significant tool of monetary policy around the globe. Lastly, after the crises, fiscal policy has no significant influence on the output gap.

Furthermore, Jawadi, Mallick and Sousa (2015) assessed the existence of the possibility of accommodating stances between monetary and fiscal policies in BRICS - Brazil, Russia, India, China, and South Africa. The results reveal a strong connection between the policies, which is crucial for economic decision making. Even though monetary contractions tighten the liquidity market and reduce real sector economic activities whereas, Keynesian effects are being experienced from the shocks in government expenditure. Kliem, Kriwoluzky and Sarferaz (2016) 
assessed the implication of monetary and fiscal policy interaction on Germany, the US, and Italy for a period 1965 - 1999. The results of the simple regressions and that of the vector autoregressions show very-low-frequency effects, and efficiency of fiscal policy on inflation even combined with monetary policy during the period of the independent central bank. Though, fiscal policy is more pronounced in time of accommodative monetary authorities or less dependency of central banks. Also, the result of the DSGE model confirms the existence of a low relationship and outcome of fiscal policy on inflation when combined with monetary policy.

Nevertheless, Lawal, Somoye, Basajide, and Nwanji (2018) analyzed the effect of monetary and fiscal policy interaction on stock market behavior in Nigeria using ARDL and EGARCH models. From the study, the interactions of the policies affect the returns of the stock market in the country. Also, the existence of long-run co-integration has been established between stock market behavior and the interaction of the policies. The shocks from the interactions of the policies also result in shocks of the stock market behavior. The study recommends gauging the two policies in a single model when formulating policies on stock markets in the country.

The review of the previous studies disclosed inconsistent findings in terms of the nature of the effect of the interactions between the two policies on the economy. This implies that research conducted in one nation cannot be used on or generalized to another nation. Also, the recent study conducted in Nigeria is limited to the effect of the interactions on the two policies on stock market behavior. Moreover, the country is experiencing high rates of inflation despite implementations of both monetary and fiscal policies at different points of time. What is not tried is the concurrent implementation of the two policies together. Therefore, there is a need to investigate the effect of the interaction of the two policies on inflation in Nigeria.

\section{Methodology}

Source of Data: Data was sourced from World Development Indicators (WDI) for the period of study 1970 - 2016 data for Nigeria.

Variables: Inflation being an increase in the general consumer price level, is the dependent variable in this study. Broad Money is a representation of the total money supply in the economy. Gross Domestic Products (GDP) is the proxy of national income, and the lending interest rate is used as 
the interest rate of the studying nation. All data are transformed, for uniformity purposes, to the logarithm.

Econometric Techniques: The paper makes use of Autoregressive Distributed Lag Model (ARDL) given that the series or variables are not integrated in the same order having inflation stationary at a level while the rest of the variables are stationary at first difference.

Theoretical Framework: This study consists of the combination of monetary and fiscal policies and, therefore, can best be understood using the combination of Monetarist and Keynesian theory of inflation. The Monetarist theory of inflation maintained that inflation in any country is solely caused by money supply and, therefore, can best be remedied by monetary policy. Keynesian theory believed that inflation is majorly caused by excess demand oversupply and, therefore, can best be solved by fiscal measures (fiscal policy). The study utilized Fisher's Equation for monetary policy (Equation '1') and liquidity preference Equation for fiscal policy (Equation '2') as:

$M V=P Y$

$\frac{M_{t}}{P}=a Y^{\beta_{1}} r^{\beta_{2}}$

where money supply multiplied by the velocity of money in circulation is equivalent to price level multiplied by income in the first Equation. The second equation shows that income and interest rates influence the total money demand.

Derivation of the monetary policy function (solve for $\mathrm{P}$ in Equation 1)

$P=\frac{M V}{Y}$

Take the log of both sides of the Equation [3]

$\log P=\log M+\log V-\log Y$

Setting $\log \mathrm{P}=\hat{\mathrm{P}}, \log \mathrm{M}=\hat{\mathrm{M}}, \log \mathrm{V}=\hat{\mathrm{V}}$, and $\log \mathrm{Y}=\hat{\mathrm{Y}}$

$\hat{P}=\hat{M}+\hat{V}-\hat{Y}$ 
Changes in any of the variable in the right-hand side of the Equation [5] will lead to a change in the price level as depicted in Equation [6]

$\Delta \hat{P}=\Delta \hat{M}+\Delta \hat{V}-\Delta \hat{Y}$

Velocity is constant therefore $\Delta \hat{V}=0$, therefore;

$\Delta \hat{P}=\Delta \hat{M}-\Delta \hat{Y}$

Equation [7] is the inflation Equation of monetarist, to implement monetary policy, an interest rate is needed which should be added to the Equation [7] as indicated in Figure 2., this is presented in Equation [8]

$\Delta \hat{P}=\Delta \hat{M}-\Delta \hat{Y}+\Delta \hat{r}$

Therefore, the monetary inflation function is presented as:

$I N F=f\left(M_{2}, Y, r\right)$

Derivation of the fiscal policy function (solve for P in Equation [2]

Taking the log of both sides

$\log M_{t}-\log P=\log a+\beta_{1} \log Y+\beta_{2} \log r$

At the equilibrium of the money market $\mathrm{M}_{t}=\mathrm{M}_{2}$ money demand equivalent to the money supply, therefore:

$\log M_{2}-\log P=\log a+\beta_{1} \log Y+\beta_{2} \log r$

Make $\log \mathrm{P}$ the subject of the formula

$\log P=\log M_{2}-\log a-\beta_{1} \log Y-\beta_{2} \log r$

Given that $\log a$ is constant

Hence, the final function of inflation for fiscal policy is 
$I N F=f\left(M_{2}, Y, r\right)$

Which is the same with that of monetary policy in Equation [9], and the two policies signify that inflation can be affected by money supply, income and interest rate in the economy; they only differ in the nature of the effect (positive/negative) of some variable on inflation. Table 1 summarized the difference between the policies mentioned.

Table 1: Nature of variable effect on inflation based on policy presumption

\begin{tabular}{|c|c|c|}
\hline Variable & Monetary Policy & Fiscal Policy \\
\hline Money Supply & + and it should be significant & $\begin{array}{l}+/- \text { Insignificant regardless of the } \\
\text { sign. }\end{array}$ \\
\hline Income & +significant & + Significant \\
\hline Interest rate & - Significant/Insignificant & + Significant \\
\hline
\end{tabular}

The most important variable in monetary policy is the money supply, which is presumed to be positively influencing inflation. Whereas, money supply could have dual nature of influence on inflation depending on the state of the economy due to the presumptions made by Keynes (1936) that increase in money supply, at the level below full employment (where involuntary unemployment exists), will not affect price level but rather it will only affect/increase the level output and employment level. To Keynes, it is merely when the money supply is increased, and there is no room for an increase in output and employment that it will lead to an increase in the price level. Therefore, in developing economies where resources are not fully utilized, an increase in the money supply should be expected to increase the level of output and employment. Also, the interest rate has an inverse influence on inflation according to monetary policy (as in Figure 2) while it affects inflation positively based on fiscal policy (as in Figure 3).

Model Specification: Following Equation [8] and Equation [12] the econometric function is specified as follows:

$l I N F_{t}=\beta_{0}+\beta_{1} l M_{2, t}+\beta_{2} l Y_{t}+\beta_{3} l r+\varepsilon_{t}$

here $l I N F$ is inflation, $l M 2$ is the money supply; $l Y$ is the $G D P$ representing income, $l r$ is the lending interest rate, $\beta_{i}$ are parameters, $\mathrm{t}$ is time signifies time-series data, and $\varepsilon$ is the error term. 
Then ARDL function is;

$$
\begin{aligned}
\Delta l I N F_{t}=\beta_{0} & +\sum_{k=0}^{n} \beta_{1} \Delta l M_{2, t-k}+\sum_{k=0}^{n} \beta_{2} \Delta l Y_{t-k}+\sum_{k=0}^{n} \beta_{3} \Delta l r_{t-k}+\sum_{k=1}^{n} \beta_{4} \Delta l I N F_{t-k}+\mathrm{a}_{1} l M_{2, t-1} \\
& +\mathrm{a}_{2} l Y_{t-1}+\mathrm{a}_{3} l r_{t-1}+\mathrm{a}_{4} l I N F_{t-1}+\varepsilon_{t}
\end{aligned}
$$

where $\mathrm{a}_{i}$ are long-run coefficients and $\beta_{i}$ short-run coefficients, the rest as defined in the previous Equations.

The short-run and long-run equations are presented in Equation [16] and Equation [17] as follows:

$$
\begin{aligned}
\Delta l I N F_{t}=\beta_{0} & +\sum_{k=0}^{n} \beta_{1} \Delta l M_{2, t-k}+\sum_{k=0}^{n} \beta_{2} \Delta l Y_{t-k}+\sum_{k=0}^{n} \beta_{3} \Delta l r_{t-k}+\sum_{k=1}^{n} \beta_{4} \Delta l I N F_{t-k}+\vartheta_{0} E C T_{t-1} \\
& +\varepsilon_{t}
\end{aligned}
$$

where $E C T$ is the error correction term, $\vartheta_{0}$ is the speed of adjustment. The rest of the variables are already defined.

$l I N F_{t}=\mathrm{a}_{0}+\sum_{k=0}^{n} \mathrm{a}_{1} \Delta l M_{2, t-k}+\sum_{k=0}^{n} \mathrm{a}_{2} \Delta l Y_{t-k}+\sum_{k=0}^{n} \mathrm{a}_{3} \Delta l r_{t-k}+\varepsilon_{t}$

All as defined in the previous Equations.

\section{Discussion of Results}

In this section, the findings of the research are highlighted, starting with the descriptive statistics, which is presented in Table 2, to check the nature of the variable. From the table, the average inflation rate is 2.66 . The money supply is 25.93 , income is 24.73 , and the interest rate is 2.63 as their averages; all values are in logarithm form.

Table 2; Descriptive statistics of the variables

\begin{tabular}{lcccc}
\hline & $l I N F$ & $l M_{2}$ & $l Y$ & $L r$ \\
\hline Mean & 2.66 & 25.93 & 24.72 & 2.63 \\
Median & 2.56 & 26.01 & 24.31 & 2.82 \\
Maximum & 4.29 & 30.67 & 27.07 & 3.45 \\
Minimum & 1.24 & 20.70 & 22.94 & 1.79 \\
Std. Dev. & 0.70 & 3.13 & 1.12 & 0.47
\end{tabular}




$\begin{array}{lcccc}\text { Skewness } & 0.59 & 0.02 & 0.80 & -0.44 \\ \text { Kurtosis } & 2.88 & 1.76 & 2.58 & 1.83 \\ & & & & \\ \text { Jarque-Bera } & 2.77 & 3.04 & 5.31 & 4.18 \\ \text { Probability } & 0.25 & 0.22 & 0.07 & 0.12 \\ & & & & 123.43 \\ \text { Sum } & 124.80 & 1218.62 & 1161.99 & 10.10 \\ \text { Sum Sq. Dev. } & 22.55 & 452.00 & 57.78 & 47 \\ & & & & 47 \\ \text { Observations } & 47 & 47 & & \end{array}$

Unit Root Test Results

Table 3 presents the result of unit root test conducted on the variables which shows that they are not integrated in the same order with only the inflation rate that is stationary at level while the rest of the variables are stationary at first difference, based on the Philips Peron (PP), and Augmented Dickey-Fuller (ADF) unit root tests.

Table 3; Unit Root test results

\begin{tabular}{lllll}
\hline- & PP & PP & ADF & ADF \\
\hline Variables & Level & 1st Difference & Level & 1st Difference \\
\hline$l I N F$ & $-3.67^{* *}$ & - & $-3.89^{*}$ & - \\
& $(0.01)$ & & $(0.00)$ & \\
$l M 2$ & -1.78 & $-4.06^{* *}$ & -2.88 & $-4.05^{* *}$ \\
$l Y$ & $(0.70)$ & $(0.01)$ & $(0.18)$ & $(0.01)$ \\
& -1.25 & $-6.10^{*}$ & -1.18 & $-6.09^{*}$ \\
$l r$ & $(0.89)$ & $(0.00)$ & $(0.90$ & $(0.00)$ \\
& -1.27 & $-6.51^{*}$ & -1.12 & $-6.50^{*}$ \\
& $(0.88)$ & $(0.00)$ & $(0.91)$ & $(0.00)$ \\
\hline
\end{tabular}

Notes: “*” “**” “***” Represents Statistically Significant at 1, 5, and 10 Percent levels.

The General Modelling

Table 4 presents the $\operatorname{ARDL}(2,2,2,2)$ estimation that was subsequently used for bound test and later Wald test. The model estimated based on lag 2. The second lag is chosen to ensure that the model is optimal- i.e., to be free from serial correlation and heteroskedasticity, as well as to be dynamically stable. The corresponding Akaike Information Criteria value, of the chosen lag, is approximately 1.92 . 
Table 4: Result of ARDL $(2,2,2,2)$ Estimation

\begin{tabular}{lcccc}
\hline Variable & Coefficient & Std. Error & $t$-Statistics & Prob \\
\hline$l I N F(-1)$ & 0.42 & 0.16 & 2.70 & 0.01 \\
$l I N F(-2)$ & -0.32 & 0.17 & -1.85 & 0.07 \\
$l M_{2}$ & -0.75 & 0.79 & -0.95 & 0.35 \\
$l M_{2}(-1)$ & 2.45 & 1.27 & 1.93 & 0.06 \\
$l M_{2}(-2)$ & -2.00 & 0.75 & -2.68 & 0.01 \\
$l Y$ & 0.08 & 0.45 & 0.18 & 0.86 \\
$l Y(-1)$ & 0.19 & 0.55 & 0.35 & 0.73 \\
$l Y(-2)$ & 0.13 & 0.40 & 0.33 & 0.74 \\
$L r$ & 0.22 & 0.77 & 0.29 & 0.78 \\
$l r(-1)$ & 0.19 & 0.98 & 0.19 & 0.85 \\
$l r(-2)$ & 0.98 & 0.77 & 1.27 & 0.21 \\
$C$ & -3.90 & 5.16 & -0.76 & 0.45 \\
\hline
\end{tabular}

Bound Test

The bound test confirms the existence of a long-run relationship among the variables with the result of critical values of $\mathrm{I}(0)$ and $\mathrm{I}(1) ; 4.29$ and 5.61, respectively, based on the Pesaran table at one percent, both are lower than the F-statistics value calculated 6.82 .

The Wald test results presented in Table 5, implies that the coefficients of all the variables combined have effects on inflation. Also, coefficients of money supply combined have effects on inflation. On the other hand, the result shows that the combined coefficients of income have no effects on inflation. Similarly, the combined coefficients of interest rates have no effect on inflation in the country. Constant on its own also does not affect inflation.

Table 5, Wald Test Results

\begin{tabular}{llll}
\hline Null Hypothesis & $F$-statistics & Prob & Result \\
\hline All coefficients are zero & $85.91^{*}$ & 0.00 & Reject the null \\
$l I N F$ coefficients are zero & $3.97^{*}$ & 0.03 & Reject the null \\
$l M 2$ coefficients are zero & $3.15^{*}$ & 0.04 & Reject the null \\
$l Y$ coefficients are zero & 0.70 & 0.56 & They are Zero \\
$l r$ coefficients are zero & 1.60 & 0.21 & They are Zero \\
Constant is zero & 0.57 & 0.45 & It is Zero \\
\hline
\end{tabular}

Notes: * Represents Significant F-Statistics. 


\section{The Short-Run and Long-Run Results}

Table 6 presents the short-run and the long-run results of the estimation. The results show that the lag value of the money supply is inflationary during the short-run, and its coefficient is significant at a five percent level, and it shows that a one percent increase in money supply leads to an increase in inflation by two percent after one year, during the short run. The speed of adjustment is around 89.68 percent, and it is significant at one percent level. The rest of the variables are insignificant in explaining the inflation changes during the short-run. The short-run result conforms with the arguments of the monetarist theory of inflation that only money supply can influence inflation. Therefore, the stabilization policy that can salvage the inflationary situation of the country during the short-run is monetary policy.

Also, from the table, the long-run result shows that only the rate of interest is significant and can influence inflation positively. Specifically, a one percent increase in interest rate will result in approximately a 1.6 percent increase in the inflation rate. The rest of the variables are insignificant in explaining the changes in inflation during the long-run. The long-run result conforms the Keynesians' arguments of money supply have no effect on inflation when resources are not fully utilized and conforms to their argument of the direct relationship of interest rate and inflation. Therefore, the best stabilization policy for long-run inflation based on this result is fiscal policy.

Table 6: The Short-Run and Long-Run ARDL Result

Short-Run Cointegrating Form

\begin{tabular}{ccccc}
\hline Variable & Coefficient & Std. Error & t-Statistic & Prob. \\
\hline $\mathrm{D}(\mathrm{IINF}(-1))$ & 0.32 & 0.17 & 1.85 & 0.07 \\
$\mathrm{D}\left(\mathrm{IM}_{2}\right)$ & -0.75 & 0.79 & -0.95 & 0.35 \\
$\mathrm{D}(\mathrm{lM} 2(-1))$ & $2.00^{*}$ & 0.75 & 2.68 & 0.01 \\
$\mathrm{D}(\mathrm{lY})$ & 0.08 & 0.45 & 0.18 & 0.86 \\
$\mathrm{D}(\mathrm{lY}(-1))$ & -0.13 & 0.40 & -0.33 & 0.74 \\
$\mathrm{D}(\mathrm{lr})$ & 0.22 & 0.77 & 0.29 & 0.78 \\
$\mathrm{D}(\mathrm{lr}(-1))$ & -0.98 & 0.77 & -1.27 & 0.21 \\
$\mathrm{CointEq}(-1)$ & $-0.90 *$ & 0.18 & -5.06 & 0.00 \\
\hline
\end{tabular}

Cointeq $=$ LINF $-(-0.3326 *$ LM2 + 0.4556*LGDP + 1.5533*LINT -4.3526 ) 


\begin{tabular}{ccccc}
\hline Variable & Coefficient & Std. Error & t-Statistic & Prob. \\
$\mathrm{IM}_{2}$ & -0.33 & 0.17 & -1.94 & 0.06 \\
$\mathrm{lY}$ & 0.46 & 0.34 & 1.33 & 0.19 \\
$\mathrm{lr}$ & $1.55^{*}$ & 0.66 & 2.37 & 0.02 \\
$\mathrm{C}$ & -4.35 & 5.84 & -0.74 & 0.46 \\
\hline
\end{tabular}

Notes: * represents statistically significant at 5 percent level.

Post-estimation Diagnostic Checks

The research conducted post-estimation checks to ensure stability and best fit of the estimated model, and they are:

- Breusch-Godfrey Serial Correlation LM Test conducted shows that the model is free from serial correlation with the F-Statistic value of 0.952388 and a probability value of 0.2632 .

- Breusch Pagan-Godfrey heteroskedasticity test conducted indicated that the estimated model is free from heteroskedasticity with an F-statistic value of 0.920288 and a probability value of 0.5330 .

- Jarque-Bera statistics with value 0.446342 and probability 0.8000 indicate that the errors are normally distributed.

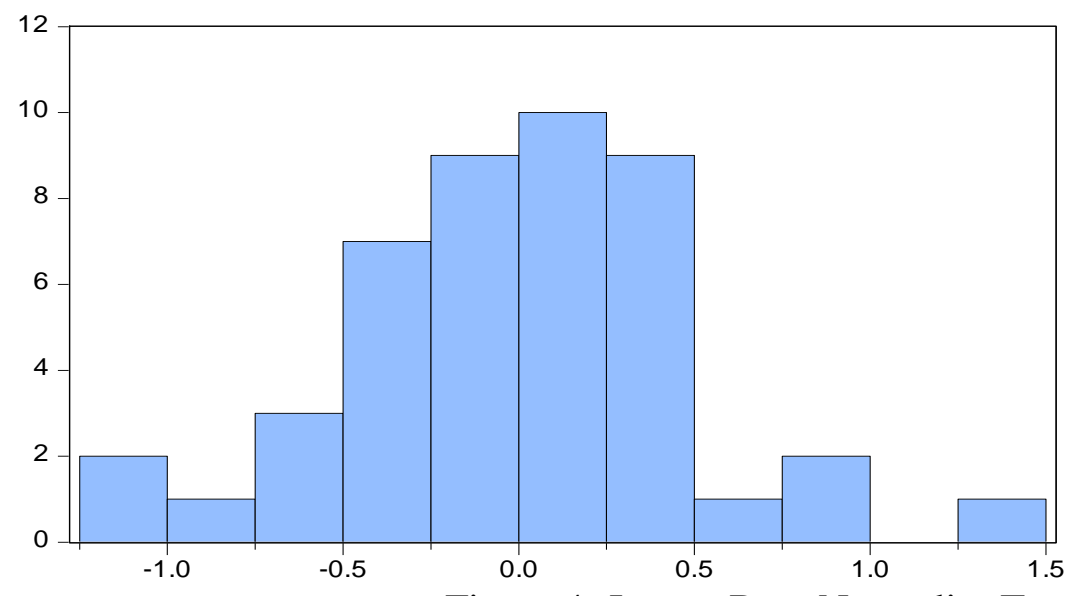

\begin{tabular}{lr}
\multicolumn{2}{l}{ Series: Residuals } \\
Sample 1972 2016 \\
Observations & 45 \\
Mean & $9.46 \mathrm{e}-15$ \\
Median & 0.013707 \\
Maximum & 1.307285 \\
Minimum & -1.159907 \\
Std. Dev. & 0.489117 \\
Skewness & 0.070779 \\
Kurtosis & 3.466916 \\
& \\
Jarque-Bera & 0.446342 \\
Probability & 0.799978 \\
\hline
\end{tabular}

Figure 4: Jarque-Bera Normality Test

- CUSUM and CUSUM of squares presented in Figure 5 and Figure 6 respectively indicate that the estimated model is dynamically stable. 


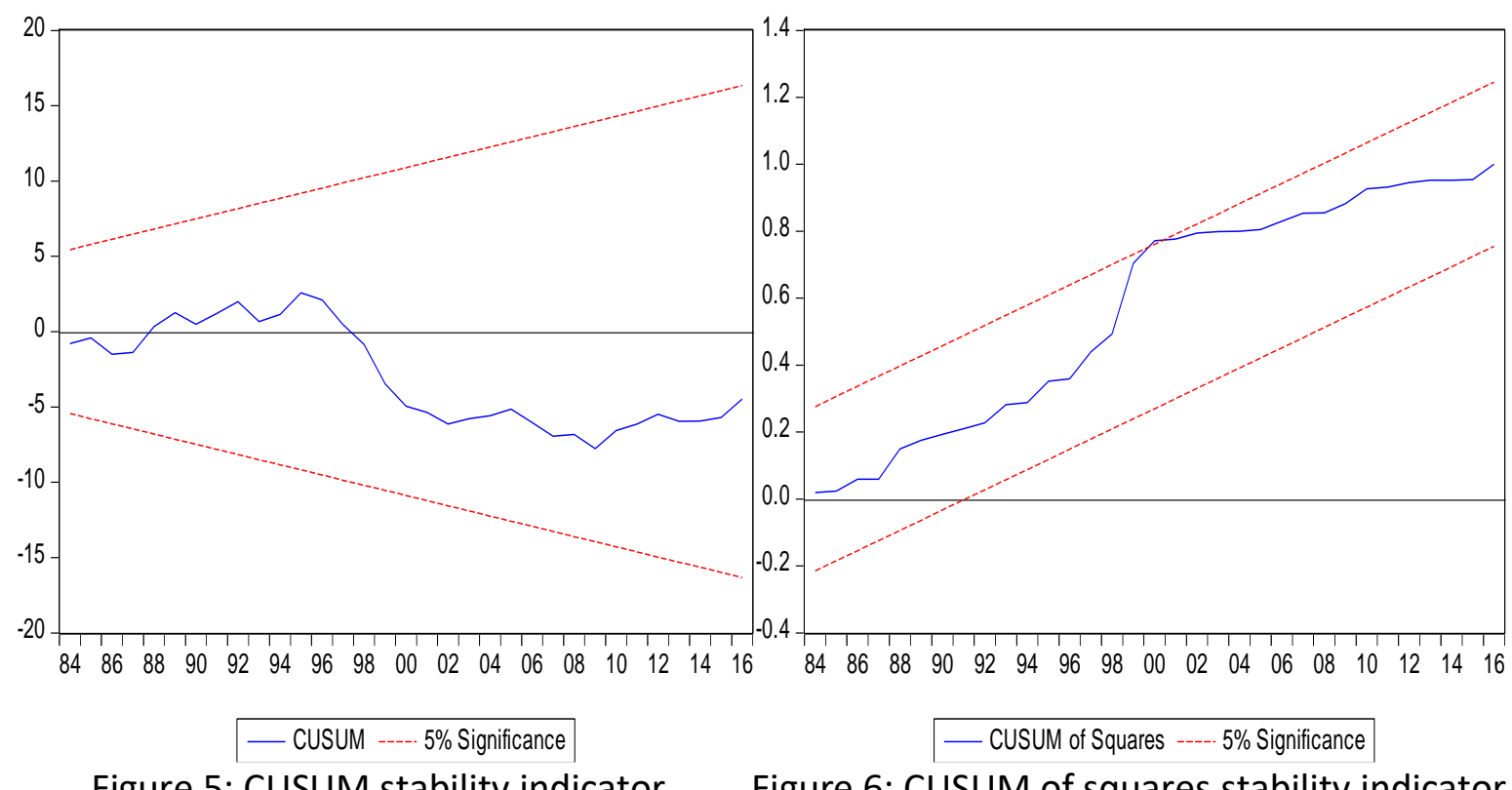

Figure 5: CUSUM stability indicator. Figure 6: CUSUM of squares stability indicator

\section{Conclusion}

The post-estimation diagnostics checks conducted reveal that the assessed model is not only dynamically stable but also free from all the problems of serial correlation and heteroskedasticity, with the errors being normally distributed. During the short-run, only the lag value of money supply is inflationary and significant, which is in accord with monetarist arguments, and therefore, the best stabilization policy, during the short-run in Nigeria, is monetary policy. The speed of adjustment is about 89.68 percent, and it is significant at one percent level. It is very fast. The long-run result indicates that only the rate of interest is inflationary and significant with a positive or direct effect on inflation while the rest of the variables are insignificant. This is in accord with the Keynesians' arguments of the positive or direct effect of interest rate on inflation (fiscal policy), and their argument of money supply has no effect on inflation where involuntary unemployment exists. Therefore, the best stabilization policy based on the long-run result is fiscal policy. Based on the results of the estimation, the simultaneous implementation of monetary and fiscal policy in Nigeria is feasible when tackling inflation, as the effect of monetary policy is in the short-run while that of fiscal policy is in the long-run. The policy implication, here, indicates that when the two 
policies are implemented simultaneously, the effect of monetary policy can be seen within a year (which is the short-run based on the study period) while the effect of fiscal policy can be seen in the long-run. The long-run here is less than two short-run periods as indicated by the speed of adjustment which is 89.68 percent. i.e. each short-run period represents about 89.68 percent of one long-run period and hence, the long-run is reach in less than two years i.e. less than two short-run periods.

\section{References}

Alavi, S. E., Moshiri, S., \& Sattarifar, M. (2016). An analysis of the efficiency of the monetary and fiscal policies in Iran economy using IS-MP-AS model. Procedia Economics and Finance, 36, 522-531.

Albonico, A., \& Rossi, L. (2017). Inflation bias and markup shocks in a LAMP model with strategic interaction of monetary and fiscal policy. Journal of Macroeconomics, 52, 39-55.

Anwar, S. \& Islam, I. (2011). Should developing countries target low, single-digit inflation to promote growth and employment? International Labour Organisation, Employment Working Papers No. 87, International Labour Office, Geneva 22.

Babalola, O. O, Danladi, J. D., Akomolafe, K. J. \& Ajiboye, O. P. (2015). Inflation, Interest Rates and Economic Growth in Nigeria. European Journal of Business and Management, 7(30), 91 $-102$.

Bianchi, F., \& Ilut, C. (2017). Monetary/fiscal policy mix and agents' beliefs. Review of Economic Dynamics, 26, 113-139.

Cavalcanti, M. A., Vereda, L., Doctors, R. D. B., Lima, F. C., \& Maynard, L. (2018). The macroeconomic effects of monetary policy shocks under fiscal rules constrained by public debt sustainability. Economic Modelling. (In press). 
Cevik, E. I., Dibooglu, S., \& Kutan, A. M. (2014). Monetary and fiscal policy interactions: Evidence from emerging European economies. Journal of Comparative Economics, 42(4), 1079-1091.

Da Silva, C. G., \& Vieira, F. V. (2017). Monetary and fiscal policy in advanced and developing countries: An analysis before and after the financial crisis. The Quarterly Review of Economics and Finance, 63, 13-20.

Danlami, I. A. (2020). Revisiting the West African Commonwealth Countries' exchange rate passthrough to inflation. Academic Journal of Economic Studies, 6(1), 70 - 77.

Danlami, I. A., Hassan, S. \& Hidthiir, M. H. (2020). Assessing the asymmetry of the exchange rate pass-through to inflation in West African Commonwealth Countries. Academic Journal of Economic Studies, 6(1), 93 - 109.

Danlami, I. A., Hidthiir, M. H. \& Hassan, S. (2017). Dynamics of inflation in developing economies: A quest for conceptual framework. IOSR Journal of Humanities and Social Science, 22(10), $53-59$.

Hartmann, M., Herwartz, H. \& Ulm, M. (2017). A comparative assessment of alternative ex-ante measures of inflation uncertainty. International Journal of Forecasting. 33(1), $76-89$.

Jawadi, F., Mallick, S. K., \& Sousa, R. M. (2016). Fiscal and monetary policies in the BRICS: A panel VAR approach. Economic Modelling, 58, 535-542.

Jhingan, M. L. (2011). Monetary Economics, 7th Ed. Vrinda Publications (P) Ltd., Delhi.

Kandil, M. (2015). Monetary shifts and co-movements in spending, growth and inflation: Evidence from developing and advanced countries. Borsa_Istanbul Review 15(2), 76 - 92.

Keynes, J. M. (1936). The General Theory of Employment, Interest and Money, Macmillan, New York.

Kliem, M., Kriwoluzky, A., \& Sarferaz, S. (2016). Monetary-fiscal policy interaction and fiscal inflation: A tale of three countries. European Economic Review, 88, 158-184. 
Lawal, A. I., Somoye, R. O., Babajide, A. A., \& Nwanji, T. I. (2018). The effect of fiscal and monetary policies interaction on stock market performance: Evidence from Nigeria. Future Business Journal, 4(1), 16-33.

Phiri, A. (2012). Threshold effects and inflation persistence in South Africa, Journal of Financial Economic Policy, 4(3) $247-269$.

Risso, W. A. \& Sanchez-Carrera E. J. (2009). Inflation and Mexican economic growth: long-run relation and threshold effects. Journal of Financial Economic Policy 1(3) 246 - 263.

Wang, Y., Chen, C. R., Chen, L. \& Huang, Y. S. (2016). Overinvestment, inflation uncertainty, and managerial overconfidence: Firm-level analysis of Chinese corporations. The North American Journal of Economics and Finance 38 (2016), 54-69.

World Development Indicators (WDI) (2018). www.worldbank.org/data 